ARTICLES 
E. Valencia-0spina - 9789004400610 Downloaded from Brill.come4/26/2023 01:31:16AM via free access 


\title{
THE INTERNATIONAL COURT OF JUSTICE AND INTERNATIONAL ENVIRONMENTAL LAW *
}

\author{
E. Valencia-Ospina* *
}

To speak on international environmental law and the International Court of Justice might seem a rather daunting task because the Court has never had to decide on environmental issues except in the Nuclear Tests cases (I.C.J. Reports 1974, pp. 253 and 457) and tangentially in the Fisheries Jurisdiction cases (I.C.J. Reports 1975, pp. 3 and 175) and some continental shelf delimitation cases. Thus my task today is not to analyse the Court's current environmental jurisprudence but rather to assess the Court's potential role in the future development of international environmental law. I am encouraged in this regard by the significant advances that have been made to date in the development of international legal norms. These derive from the Trail Smelter Arbitration (16 April 1938, 3 U.N.R.I.A.A. 1931 (1949)), the Nuclear Tests cases and certain other international judicial decisions and arbitrations, from various global and regional conventions including the United Nations Convention on the Law of the Sea and from pronouncements of the United Nations, particularly the 1972 United Nations Declaration on the Human Environment.

While the rules governing international environmental law are still in their embryonic stages and are often cast in vague general terms, the number and frequency of international conventions and treaties reflect a clear desire on the part of the world community to control the threat to the global environment caused by pollution.

I would like at the outset to make two observations of general import. First, the international judge is no substitute for States in the "legislative" function they assume within the international legal order, directly through multilateral conventions and treaties or indirectly, by setting up

*. Address given at the thirty-first session of the Asian-African Legal Consultative Committee at Islamabad, January 1992.

**. Registrar of the International Court of Justice.

Ko Swan Sik et al. (eds.), Asian Yearbook of International Law, Volume 2, 1-10 (c) 1994 Kluwer Academic Publishers. Printed in the Netherlands 
specialized organs, such as the Intemational Law Commission of the United Nations, entrusted with the preparatory work for the conventional codification and development of international law. Second, it must be stressed that the large majority of cases of transfrontier pollution would be best settled by conventional regimes of easy application enabling individuals who are victims to obtain prompt satisfaction from municipal courts. It is also within the framework of such conventional regimes that it will be possible to implement specific rules relating to the preservation of the environment, and to exchange information.

As against this, the Court, as the foremost international judicial organ, seems ideally suited to interpret treaties and conventions that are the product of the legislative functions of States, and to act as a Court of last resort where local remedies and diplomatic exchanges have failed. One fact that cannot be denied is that pollution is international in character. This characteristic of pollution not only rests upon a physical reality - of which transfrontier pollution provides the clearest possible illustration - but also on a juridical one; international law is susceptible of dealing, for example, with problems of maritime pollution in which the sources of pollution of the coasts of a State $\mathrm{X}$ may be a vessel flying the flag of State $\mathrm{Y}$ and commissioned on behalf of a company of a third nationality, $\mathrm{Z}$. The case of the Amoco Cadiz starts to illustrate the intricacy of the problems of international law that may arise. The complexity of the legal issues involved demonstrates the need for recourse to a judicial organ specializing in international law.

In the first part of this speech, I will outline some of the difficulties that will face litigants who seek to invoke the Court's jurisdiction in an international environmental dispute.

In the second part I will examine the structure and jurisdiction of the Court with particular emphasis on powers of the Court that are of potential application to international environmental disputes.

The final part of this speech will outline a number of environmental legal issues upon which clarification by the Court would be useful.

\section{Difficulties facing the Court's future role in environmental decision-making}

Several obstacles exist, in the current regime of international environmental law, to use of the Court to adjudicate environmental issues. A close examination of these obstacles reveals that they are not insurmountable.

First, restrictive rules of standing limit the scope of environmental problems for which the Court could provide solutions. The Court is normally inaccessible to non-State claimants. To combat this standing diffi- 
culty, States must elevate the private injury suffered to the international level. States have already done so in numerous instances. For example, the United States and Canada did so in the 1935 Treaty upon which the jurisdiction of the arbitration panel in the Trail Smelter case was founded.

Even more difficult is the problem of bringing a claim on behalf of shared interests, such as the protection of the ocean from marine pollution, when injuries to individual interests of the claimant State cannot be shown. Support has been growing for the actio popularis doctrine under which the complaining State might be considered as vindicating the rights of the entire international community. In the Barcelona Traction case (I.C.J. Reports 1970, pp. 3, 32), the Court recognized the existence of a certain category of rights of such importance that "all States can be held to have a legal interest in their protection; they are obligations erga omnes $^{n}$. Recognition by States of the actio popularis doctrine in the field of environmental law would reflect a fundamental change in the way States have traditionally perceived the international legal order. But one only needs to become fully aware that the problems of environmental law increasingly relate to international spaces placed outside the individual sovereignty of States (high seas, Antarctica, extra-atmospheric space) and correlatively, to certain spaces exclusively under territorial sovereignty (e.g., the Amazonian forest) to understand the need for a departure from traditional rules of standing.

Second, States have failed to agree on levels of pollution that will trigger a State's responsibility to the international community. The problem is that international environmental law involves policy and social considerations that often pull in diametrically opposite directions. Thus, economic development pits itself against environmental preservation and State sovereignty against the common heritage of mankind. The greater the cultural, social and economic differences between parties to a dispute, the more they will differ and hence the more difficult it will be to settle or avoid the dispute. This is clearly seen in the different approaches that developed and developing nations take to environmental protection. Many developing States view with suspicion environmental standards suggested by developed States on the grounds that implementation of the suggested standards would slow down their economic development and give a competitive advantage to the developed States.

The tension between temporal goals of profit maximization and the need to preserve the environment for future generations has thus made consensus on the meaning of the term pollution difficult to achieve.

The lack of consensus is underscored by the rarity of recourse to "ecostandards" in the relevant treaties and conventional provisions; they frequently include nothing more than an obligation to refrain from polluting, 
formulated in general terms. If there is to be effective enforcement of environmental international law, States must go beyond general declarations and adopt standards against which a State's polluting activity can be measured. The ecostandards provided for in many EEC regulations and directives illustrate some of the possibilities. There is also the need for States to agree upon who should bear the cost of compliance with ecostandards, a subject which will be extensively discussed at the United Nations Conference on the Environment and Development in Rio de Janeiro in June.

There is a growing lobby in support of the establishment of an international mechanism empowered to monitor and enforce the provisions of environmental treaties. Analogous powers are vested in the European Commission under EEC law. Conceivably, the Court could be empowered to play a role in connection with the decisions of such a mechanism, as does the European Court from decisions from the European Commission on environmental law.

Third, States have traditionally been reluctant to submit international environmental disputes to judicial bodies because the scarcity of jurisprudence in the area makes the outcome difficult to predict. Depending which side of the dispute they are on, States fear that a court would take a liberal, legislative approach or alternatively that it would feel constrained by formal rules of international environmental law, or more accurately the lack of such rules, to adopt a conservative approach. This traditional mistrust is reflected in provisions for dispute settlements in many environmental treaties which make arbitral or judicial adjudication dependent on common agreement to bind the parties to a dispute - so that, if one of the parties is opposed 2 to legal adjudication, this will suffice to exclude it. This runs counter to the recommendations put forward by the World Commission on Environment and Development ("the Brundtland Report") to UNEP in 1987, when it proposed as its legal principle No. 22, that "if mutual agreement on a solution or other dispute settlement arrangement is not reached within eighteen months",

". . the dispute shall be submitted to conciliation and, if unresolved, thereafter to arbitration or judicial settlement at the request of any of the concerned States". (UN Doc. A/42/47, p. 342).

The theory that the lack of a developed corpus of international environmental law makes recourse to judicial decision-making hazardous is not borne out in practice. In the Trail Smelter Arbitration, the Arbitration Panel held that a State has an obligation to prevent domestic activities from harming the environment in other countries to any significant degree. Although the decision has been criticized as merely restating a 
principle embodied in the applicable treaty, the Arbitration Panel stated for the first time a general principle that has formed the bedrock of almost all subsequent treaties relating to international environmental law. Moreover, to mitigate any conservative nature of the formal rules of international environmental law the ex aequo et bono provision of Article 38 of the Statute of the Court can be used, by agreement, to ensure that equity considerations are taken into account. Instead of turning away from legalistic solutions to environmental problems, it is important to encourage further clarification of legal standards through treaty-making and the explicit recognition of legal considerations in reaching negotiated settlements of environmental disputes.

The decision of the Trail Smelter Tribunal indicates the potential effectiveness of international tribunals. Not only did the Tribunal articulate a series of effects standards through its determination of the interests legally injured by fumes from the Canadian Smelter, but it also established emission standards for the plant to prevent further damages and set up a monitoring regime based on measurements of air quality in the effected region to ensure compliance. Equally, participation by the Court in environmental disputes would not only assist in ad hoc standard-setting in situations which involve treaty interpretation and other legal issues but would also lead to the development of a body of environmental law which, it would be hoped, would reduce the duplication of time and effort implied by an increased reliance on ad hoc tribunals.

A fourth complaint for which there is no obvious answer, is that judicial processes tend to become lengthy and problems require much faster solutions. To argue that negotiation often reflects the same problem is an inadequate defense. But the Court has recently adopted procedures designed to achieve more speedy settlements of disputes. Furthermore, in cases where there is a need for speedy action, the Court can order interim measures to maintain the status quo pending resolution of the entire dispute.

Finally, there are those who argue that the underlying questions in many environmental disputes are of such a technical nature that judges trained only in the law may have difficulty in understanding them. If the judges had no opportunity to obtain the services of experts in the relevant field this indeed would be a serious problem. But the procedures of the Court, to which I will return in more detail shortly, can be used to secure this assistance. For example, "assessors" nominated by the international organization specializing in the problem under consideration can serve as non-voting members of the deliberative body.

None of the problems identified above are insuperable if States recognize the long-term advantages in a clarification of the rules of State 
responsibility that only adjudicating institutes can provide. Dispute settlement provisions in the 1982 Law of the Sea Convention illustrate some of the possibilities. The Convention provides for certain forms of binding third-party settlements: the Court, an arbitral tribunal, a special arbitral tribunal, and an on-going Law of the Sea Tribunal with a separate Sea-Bed Disputes Chamber. When a dispute arises the States designate one of the desired procedures. If a State to a dispute fails to agree or fails to designate its preferred method of adjudication, the dispute is settled by a tribunal.

\section{Powers of the International Court of Justice}

I turn now to certain powers of the Court, often overlooked, that are potentially useful to the settlement of international environmental disputes.

Under its Statute, the Court enjoys contentious, advisory and incidental jurisdiction.

A. The contentious jurisdiction of the Court depends upon the consent of the parties. Consent can be given ad hoc, in respect of a specific dispute or in advance of any dispute by several means including a formal declaration or treaty provision. The Court has the power to form chambers of three or more judges to deal with categories of contentious cases or with a single contentious case. This power was exercised for the first time in the Gulf of Maine case. In 1985-1986, the Court considered the possible formation of a chamber to deal with environmental disputes. It took the view that it was not necessary to set up a standing special chamber, but emphasized that it might be willing to respond positively to a request for an ad hoc chamber to deal with an environmental dispute.

B. The advisory jurisdiction of the Court is open solely to principal United Nations organs and to international organizations authorized by the General Assembly. States who have an interest in the subject matter of the dispute may be called upon to furnish information. Although no international organization with a environmental portfolio has yet a right to directly invoke the advisory jurisdiction of the Court, it is not inconceivable that such an organization might apply to the General Assembly for authorization. While advisory opinions of the Court are recommendatory only, they assist in the identification and development of rules relating to international environmental law.

C. The Court's incidental jurisdiction includes powers of potential application to environmental disputes between States.

(i) The Court can grant intervenor status in contentious proceedings to States under Article 62. This is of interest in light of the ecologi- 
cal inter-relationships between States and the emerging concepts of an international community interest in the protection of the environment. A State also has a right under Article 63 to intervene when the construction of a convention to which it is a party is at issue.

(ii) The Court has the power, under Article 50 to request an individual body, bureau, commission or other organization to carry out an inquiry or give an expert opinion. This right, though rarely invoked, was exercised in the Corfu Channel case and holds potential for factually and technically complex environmental disputes.

(iii) The Court has the power, referred to earlier, under Articles 9 and 30 to appoint assessors of special technical or legal competence to sit with the Court and participate in the deliberations but not to vote.

(iv) Finally, under Article 40 (1), the Court has the power to indicate interim measures of protection to preserve the rights of parties if the circumstances so require it. Interim measures are generally warranted where there is a risk of an irreparable harm to a State's existing rights that is not compensable by reparation or restitution.

\section{Why should environmental disputes be submitted to the Interna- tional Court of Justice?}

It is important for every field of international law - particularly if it is still embryonic or going through a period of profound change to count on a "reference" organ whatever its kind. As the primary international judicial organ, the Court occupies a privileged position in relation to the interpretation of international law. Several treaties in which the international community entrusts the Court with the final decision-making power reflect this privileged status, e.g., Genocide Convention (1951) or the definition of the continental shelf on the Law of the Sea (several judgments). Moreover, a certain number of bilateral and multilateral instruments, wholly or partly devoted to preservation of the environment, provide that, albeit sometimes with significant reservations, the Court shall have jurisdiction to settle disputes relating to their interpretation or application. Article 11 of the Vienna Convention for the Protection of the Ozone Layer of 22 March 1985 is one example.

The idea that the Court is in a privileged position with respect to the interpretation of international law has arisen from the social need of the international community for such interpretation. Although the decisions of the Court bind only the parties to a particular dispute, the interest that 
has been taken in a decision is less that of ascertaining the particular result in a given case than of discovering the reasoning and rules the Court applied in reaching the result. The Court's jurisprudence therefore serves as a reference to a given aspect of the international legal order, relating to both rules of substance and to the rules specific to the functioning of that order. By providing that reference the Court as a permanent judicial institution basing its activities upon a constant jurisprudence from well established rules of procedure, is ultimately well placed to meet the expectations of States, international organizations and other protagonists on the international scene.

There are a number of examples of subjects on which clarification of international law would be useful:

(i) The Nature of International Responsibility of States under Environmental Law:

One particularly controversial point is whether responsibility incurred by a State under environmental law, constitutes responsibility for a wrongful or illicit act. That kind of issue is well known in internal regional legal orders. It involves concepts of liability, either small or large and the place occupied by the obligation of "due diligence". In international law it also forms part of a new concept which has been the subject of a great deal of discussion: the concept of "international crime".

In this respect, the International Court of Justice could contribute to the resolution of certain specific problems arising from the implementation of an obligation to make reparation independently from the establishment of a wrongful act. Indeed, as we have seen, in the field of environmental law, the existing conventional regimes often avoid tackling the question of the extent to which injury due to pollution falls within the strict framework of international responsibility. Another question currently taking shape is that of the consequences of an "international crime". The International Law Commission has in Article 19 of the provisionally adopted Part 1 of its draft articles on State Responsibility provided that the following conduct amounts to an international crime:

"A serious breach of an international obligation of central importance for the safeguarding and preservation of the human environment such as those prohibiting massive pollution of the atmospheres or of the seas." (YILQ, 1980, Vol. II, Part 2, p. 32.)

Were such a provision to be conventionally enacted or be regarded as embodying customary international law, it is clear that the Court would be in a position to apply, under appropriate circumstances, the number of criteria set out in the text. It would, to say the least, be shocking if a State 
deemed to have occasioned a "mass pollution of the atmosphere or of the seas" could escape from the responsibility which it had incurred. $A$ fortiori, this is an eloquent example of the way in which environmental problems may attain such proportions that it scarcely seems reasonable to exclude them from the application of the lex lata.

\section{(ii) The Links between International Environmental Law and other Fields} in International Law:

The recent war in the Gulf might provide a sad illustration of this point, with regard to convergence between rules aimed at preserving the environment and those that relate to the conduct of hostilities. I now refer to two other related fields, namely, international trade and human rights.

A number of activities connected with international trade pose a threat to the global environment. These activities include the transport of raw materials and the waste matter - including toxic or dangerous waste - that is generated by the exploitation or transportation of those raw materials. A large number of industrial accidents that have marked the recent history of damage to the environment relate to these same activities. Considerable efforts have already been undertaken, for example, in the normative rule-making of the International Maritime Organization, particularly with regard to the maritime transportation of hydrocarbons.

There is a clear and legal relationship between human rights and environmental law. It can readily be grasped that a degraded environment threatens an individual's health and his fundamental needs - or even his life. Over and above, the well being of future generations is at stake. It goes without saying that the link between human rights and environmental protection should be established - as was, moreover, done in 1972 by the Declaration of Stockholm on the Human Environment.

The International Court of Justice was formed in response to the needs of the international community. The foremost need of the international community at this time is to preserve the integrity of the present environment for the benefit of future generations. To respond to this need, States should shed their traditional unwillingness to commit their written aspirations to the warm glare of judicial scrutiny. They could do so by providing for recourse to the Court in the event of a dispute in the interpretation of environmental treaties or conventions that they have signed and ratified. Beyond this, States may have to rethink traditional notions of State responsibility to allow individual interests to be represented at the international level and to ensure that common areas such as oceans and air space are protected. Ultimately, it is to be hoped, States will create an international body to monitor and enforce environmental 
standards. The Court could play a role in connection with the decisions of such a body, as it has already been envisaged in the Declaration of The Hague on the Environment of 11 March 1989. 